(II) Nordic Council of Ministers

\title{
FOOD WASTE AND DATE LABELLING
}

Factors determining the durability of refrigerated foods 
FOOD WASTE AND DATE LABELLING

Factors determining the durability of refrigerated foods

ANP 2017:750

ISBN 978-92-893-5106-5 (PRINT)

ISBN 978-92-893-5107-2 (PDF)

ISBN978-92-893-5108-9 (e-PUB)

http://dx.doi.org/10.6027/ANP2017-750

(c) Nordisk Ministerråd 2017

Layout: Louise Jeppesen

Cover Photo: Wefood / Mikkel Østergaard

\section{Nordic co-operation}

Nordic co-operation is one of the world's most extensive forms of regional collaboration, involving Denmark, Finland, Iceland, Norway, Sweden, the Faroe Islands, Greenland, and Åland.

Nordic co-operation has firm traditions in politics, the economy, and culture. It plays an important role in European and international collaboration, and aims at creating a strong Nordic community in a strong Europe.

Nordic co-operation seeks to safeguard Nordic and regional interests and principles in the global community. Shared Nordic values help the region solidify its position as one of the world's most innovative and competitive.

\section{Nordic Council of Ministers}

Nordens Hus

Ved Stranden 18

DK-1061 Copenhagen $\mathrm{K}$

Phone (+45) 33960200

www.norden.org

Download nordic publications: www.norden.org/nordpub 


\section{FOOD WASTE AND DATE LABELLING}

Factors determining the durability of refrigerated foods

\section{Contents}

$4 \quad$ Best before - good after?

5 Nordic project on date labelling and food waste

7 Important findings in the project

Guide to date labelling

Legislation

Durability of the product and food waste

Packaging gas for fresh meat

Storage temperature in wholesale and retail stores

Waste in retail stores

Guidelines for the durability of opened packaging

14 Recommendations and further work 


\section{BEST BEFORE - GOOD AFTER?}

The food is often OK to eat after best before-date.

Store food according to instructions on package.

\section{What do I do when the food has passed its date of durability?}

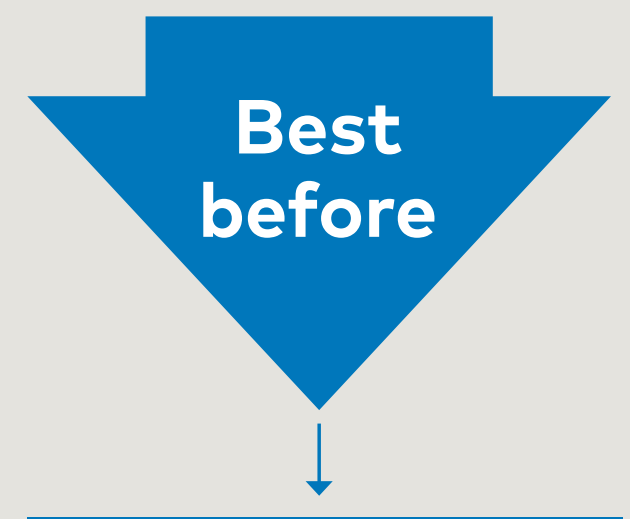

Does it Smell/Taste/Look fine?

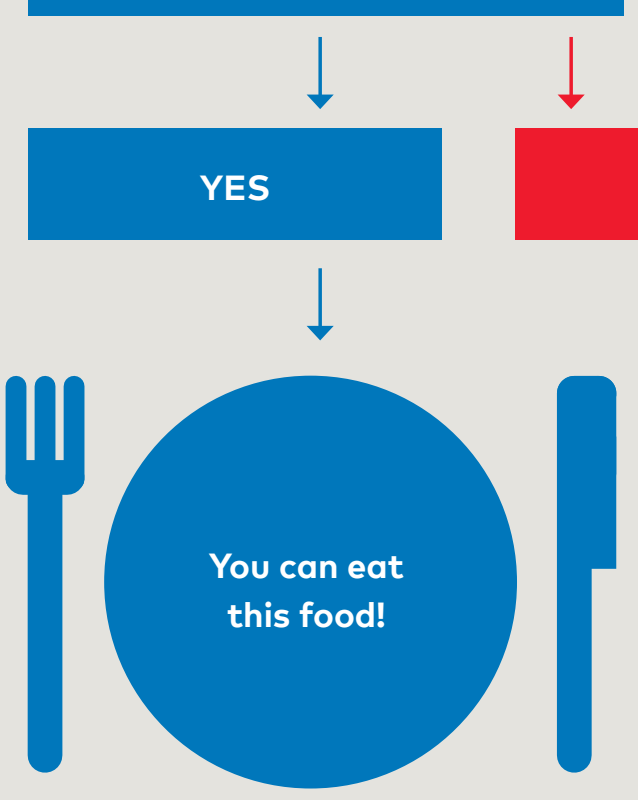

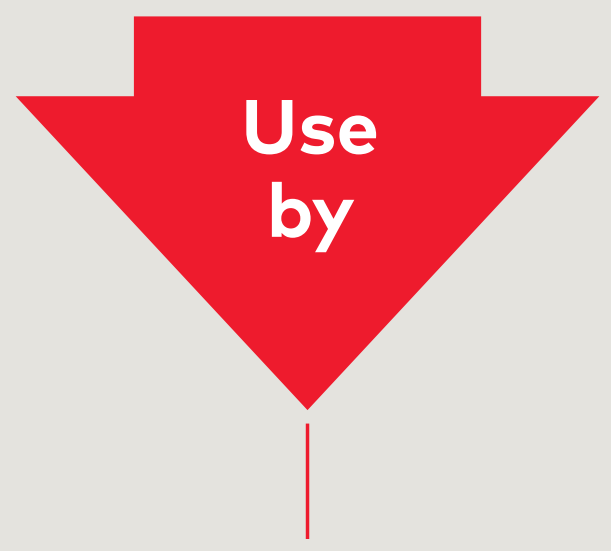

Possible health risk
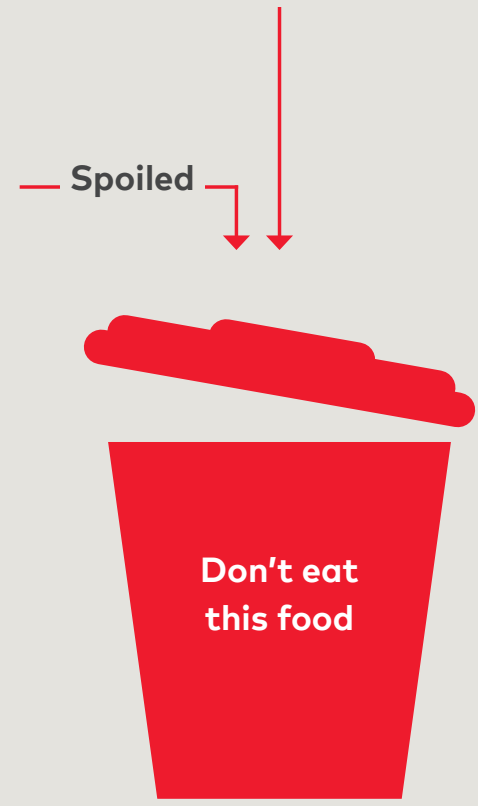


\title{
NORDIC PROJECT ON DATE LABELLING AND FOOD WASTE
}

\author{
The Nordic Council of Ministers has conducted a Nordic project \\ regarding food waste related to date labelling. To reduce food waste \\ is an important matter not only for the Nordic countries, but also \\ in the entire EU and globally. The goal to reduce food waste is also \\ amongst the UN's 17 sustainable development goals.
}

In the Nordic food waste project the following report has been published: Food waste and date labelling: Issues affecting the durability. One purpose of the study was to find out how regulations for date labelling are applied in Denmark, Finland, Norway and Sweden. Another purpose was to see how the durability of foods is affected by temperature, packaging and processing throughout the entire value chain.

Interviews with representatives of the food processing industry and retailers were conducted. A qualitative and quantitative mapping of selected products was carried out, in combination with examples from the literature. The selected products were refrigerated products (milk, cooked ham, minced meat, smoked salmon and chicken salad). The food industry was also interviewed on whether they use "best before" or "use by" date, and how they determine the durability. 


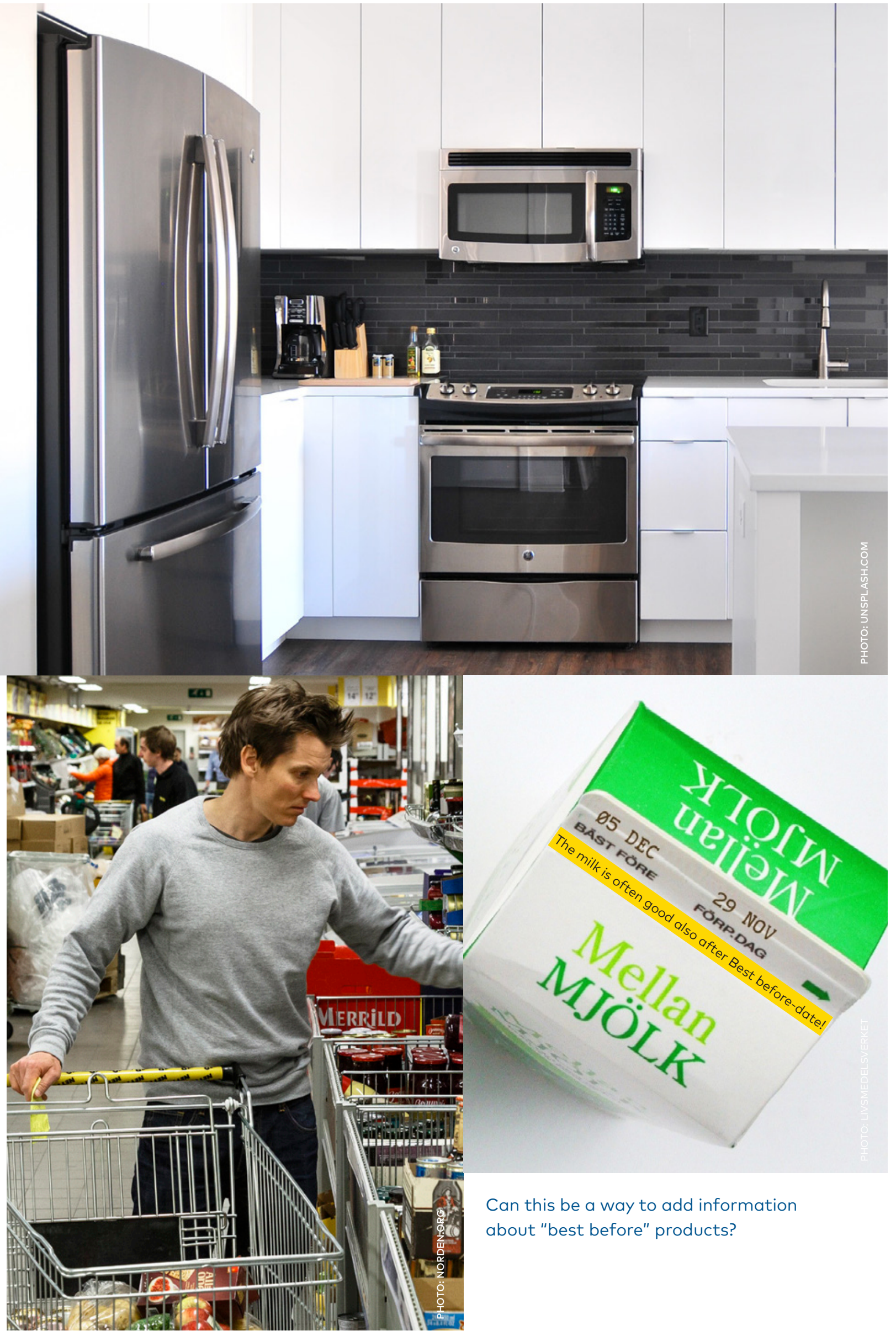




\section{IMPORTANT FINDINGS IN THE PROJECT}

The main goal of the project was to improve the use of date labelling of foods in order to contribute to reducing food waste in the Nordic countries without challenging food safety. Food waste linked to date labelling may have multiple causes and different measures can be implemented, depending on where the focus in the value chain lies.

The results from the interviews uncovered huge variations in the estimation of durability of refrigerated products. The durability within each product category varied significantly and for some product groups there were also differences in the selection of date labelling, this means the usage of "use by" or "best before".

\section{Guide to date labelling}

"Use by" labelling refers to food safety and should only be used on highly perishable foods where the storage time beyond the use bydate can lead to an immediate health risk despite storing according to instructions. This concerns pathogenic microorganisms. Foods labelled with "Use by" must not be sold or given away after the use by-date has expired. It is therefore important that the labelling "use by" is only used where it is necessary.

"Best before" labelling refers to sensory product quality and is applied on foods which are not highly perishable, i.e. for most foodstuffs. This does not concern dangerous microorganisms but concerns growth of nondangerous food spoilage microorganisms. When choosing type of date labelling it is important to distinguish between pathogenic microorganisms and food spoilage microorganisms. When labelling with "best before" the durability date should specify the period where the product maintains its specific characteristics and quality, based on the stated terms for storage in an unopened package. The durability should be set in accordance to ordinary and realistic conditions for transport, storing and sales. Also the quality of the commodities and the production conditions are important to determine the durability. When there are changes in the production, a new assessment should be made in 
order for the labelling to be correct. The regulations do not state anything regarding how to determine food durability. This is the choice and responsibility of the producers.

\section{Legislation}

The conditions for date labelling are stated by legislation which applies in the entire EU and EEA. Date labelling is regulated by the regulation on food information to consumers (EU no 1169/2011), which applies from December 2014.

According to the interviews most companies are well acquainted with the regulations and they find that it defines the authorities' role more precisely. But some producers desire guidance on how to select the type of date labelling and determine the durability period. After the regulation on food information was applied in 2014, Sweden changed its national guidance information on date labelling. The information clarifies the producers own responsibility to make an assessment based on the quality of the commodity, process, product characteristics and packaging.

There is a special EU-legislation for date labelling of eggs, according to which the maximum best before-date is 28 days from the date of laying but eggs must be delivered to the consumer within 21 days of laying. The cause for the use of such a short time period is that eggs in many EU-countries are stored at room temperature. If eggs are stored in the refrigerator the durability will extend considerably.

\section{Durability of the product and food waste}

To find the optimal date labelling it is important to make an overall assessment. The durability of a food product can be extended by changing the production process, choice of packaging or lowering the storage temperature. An extension of the provided durability is usually a balance between quality aspects and reduction of food waste. It is important to have a good production process, an uninterrupted cooling chain and low temperatures from the producer to the consumer.

In reality the producers often set the durability period based on the most demanding but realistic conditions throughout the year. As long as the business has full control and overview over the conditions, it is allowed to set different durabilities throughout the year for the same product. This means that the food products are given a dynamic du- 
rability which is adapted to the season, the quality of the commodity, temperatures and other factors. Packaging is of huge importance for the durability of the products and there are many different methods.

\section{Packaging gas for fresh meat}

From a food waste perspective it is desirable to pack meat in an oxygen free package to increase the durability time. In Norway the packaging gas used contains carbon dioxide and nitrogen $\left(\mathrm{CO}_{2} / \mathrm{N}_{2}\right)$ for most types of fresh meat. This packaging gas, as well as vacuum/ skin pack, provides longer durability compared to packaging gas with oxygen and carbon dioxide $\left(\mathrm{O}_{2} / \mathrm{CO}_{2}\right)$. Oxygen/carbon dioxide is common in the three other Nordic countries as well as in Europe in general. The reason that high oxygen packaging has such a big prevalance is that the oxygen provides the meat with an attractive red colour. Disadvantages are however shorter durability and discontinuation of the tenderisation of the meat once it is packaged. Furthermore it makes it difficult to determine the cooking time since the meat becomes brown at a lower temperature than for meat from an oxygen free packaging. Minced meat packed with high oxygen looks fully cooked already at 60 ${ }^{\circ} \mathrm{C}$ and this makes it possible for dangerous bacteria to survive. This is unfortunate since minced meat, as well as products made from minced meat, should be cooked to at least $70^{\circ} \mathrm{C}$ in the core in order to be safe for consuming.

In Norway a mapping of waste of minced meat has been carried out. It shows that a change in the packaging gas from high oxygen to $\mathrm{CO}_{2} / \mathrm{N}_{2}$ increased the durability from 10 to 18 days, and that the waste in the store was reduced with one-fourth.

In reality it will be difficult for a producer alone to change the packaging gas, since most consumers will probably select the product which is packed with high oxygen due to the colour. If producers and retailers could agree on a change there could be a possibility for the use of oxygen free packaging gas in other countries than Norway. It may then be necessary to provide the consumers with information regarding the advantages of this and regarding the change of colour. 
Specified durability in days for minced beef and minced meat. Maximum storage temperature is shown above each post (for Sweden recommended temperature)

20

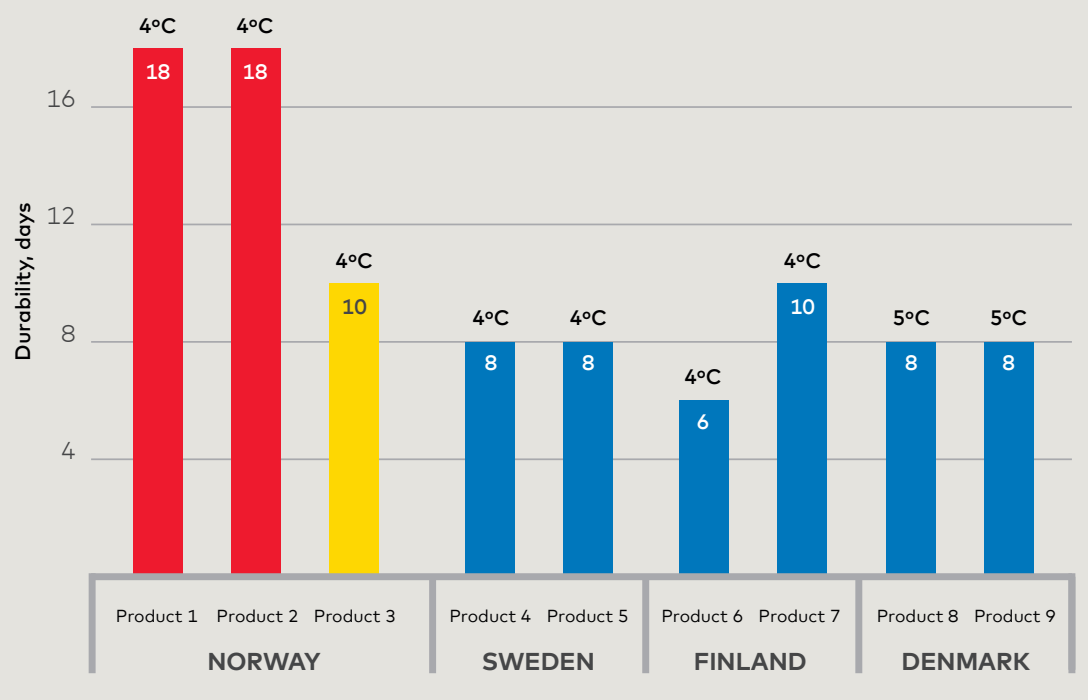

$\mathrm{CO}_{2} / \mathrm{N}_{2}$ Vacuum packaging High oxygen

The average waste of minced beef at a durability of respectively 10 and 18 days after the change of packaging gas

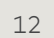




\section{Storage temperature in wholesale and retail stores}

According to the regulation on food information, foods that require special storage conditions or usage shall have such information on the label. The common EU-rules apply in all the Nordic countries. It is however national regulations that set the requirements for storage temperature in wholesale and retail stores. The requirements for the selected products in this project are shown in Table 1.

Specified storage temperature for perishable food items varies between $3-8^{\circ} \mathrm{C}$. In Sweden there is an established use of generally higher temperature, but there are also minor differences between Denmark, Finland and Norway. It is obvious that lower storage temperatures will increase food durability. If an agreement is achieved regarding mutual lower storage temperatures, it would be possible to extend the durability of perishable foods in Sweden and Denmark and for some products in Finland. This would also make the situation simpler for the producers that sell their products in more than one Nordic country. One product may then have the same required durability no matter which country it is sold in.

Table 1 National requirements for storage temperature for wholesale and retail for selected products

\begin{tabular}{|c|c|c|c|c|}
\hline & DENMARK & FINLAND & NORWAY* & SWEDEN \\
\hline Milk & $\operatorname{Max} 5^{\circ} \mathrm{C}$ & $\operatorname{Max} 6^{\circ} \mathrm{C}$ & $\operatorname{Max} 4^{\circ} \mathrm{C}$ & $\begin{array}{l}\text { No specific legal } \\
\text { requirements }\end{array}$ \\
\hline $\begin{array}{l}\text { Boiled } \\
\text { ham, } \\
\text { MAP }^{\star \star}\end{array}$ & $\operatorname{Max} .5^{\circ} \mathrm{C}$ & Max. $6^{\circ} \mathrm{C}$ & $\operatorname{Max} 4^{\circ} \mathrm{C}$ & $\begin{array}{l}\text { No specific legal } \\
\text { requirements }\end{array}$ \\
\hline $\begin{array}{l}\text { Minced } \\
\text { meat }\end{array}$ & $\operatorname{Max} 5^{\circ} \mathrm{C}$ & $\operatorname{Max} 4^{\circ} \mathrm{C}$ & $\operatorname{Max} 4^{\circ} \mathrm{C}$ & $\begin{array}{l}\text { No specific legal } \\
\text { requirements }\end{array}$ \\
\hline $\begin{array}{l}\text { Cold } \\
\text { smoked } \\
\text { salmon }\end{array}$ & $\operatorname{Max} 5^{\circ} \mathrm{C}$ & $\operatorname{Max} 3^{\circ} \mathrm{C}$ & $\operatorname{Max} 4^{\circ} \mathrm{C}$ & $\begin{array}{l}\text { No specific legal } \\
\text { requirements }\end{array}$ \\
\hline $\begin{array}{l}\text { Prepared } \\
\text { salad with } \\
\text { chicken }\end{array}$ & $\operatorname{Max} 5^{\circ} \mathrm{C}$ & $\operatorname{Max} 6^{\circ} \mathrm{C}$ & $\operatorname{Max} 4^{\circ} \mathrm{C}$ & $\begin{array}{l}\text { No specific legal } \\
\text { requirements }\end{array}$ \\
\hline
\end{tabular}

\footnotetext{
** Modified atmosphere packing.
} 


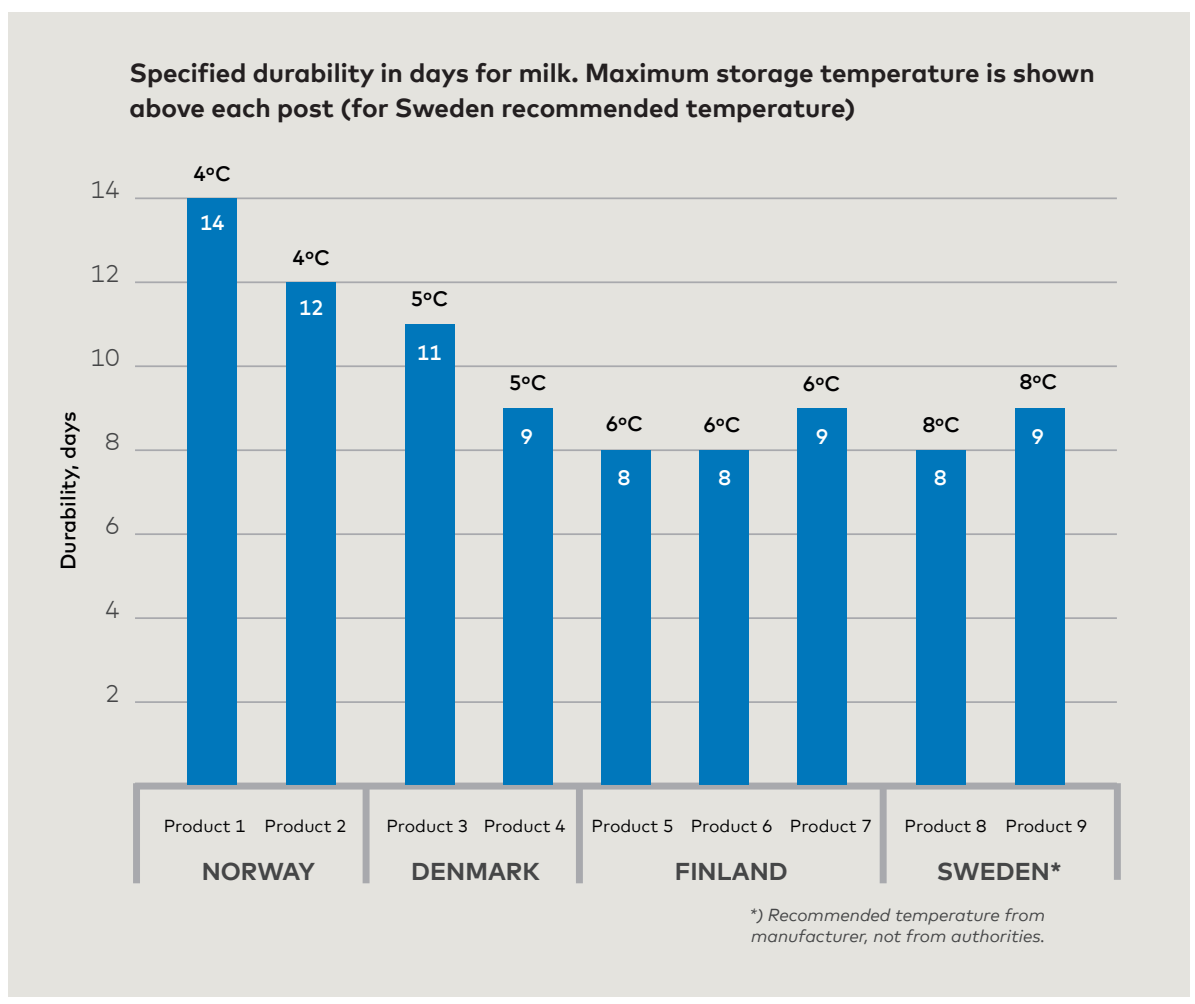

\section{Waste in retail stores}

In order to reduce food waste in retail stores it is first of all important to do a thorough assessment of the expected sales when ordering products with short durability. This should be regarded in context with how much is usually sold of the product and how wide the selection is in the product category and if there are any planned campaigns. During campaigns fewer products are sold of equivalent products. There should also be facilitations to reduce the price of products if the remaining durability of the product is short. 


\section{Guidelines for the durability of opened packaging}

It may be difficult for consumers to know for how long they can use a product after opening the packaging. Durability after opening is affected by the type of packaging, packing gas, product characteristics and storage temperature, as well as the consumers handling of the products. According to Article 25 (2) in the regulation on food information, the time limit for consumption after opening shall be indicated, where appropriate. In this project there were a series of interviews conducted with the quality control inspectors in food companies. Many producers feel that it is difficult to provide a general specification for durability after opening, because it will depend on the storing conditions and how the product is used. Some producers give precise description of the storing specifications on the packaging.

A specific durability after opening the packaging may also result in food waste, since many consumers seem to only trust the labelling and lack the knowledge to assess the quality of the food.

According to studies of consumer behaviour, many state that they are afraid of becoming ill if they eat food beyond the date labelling independently of the labelling "use by" or "best before". It is positive that the consumer receives information regarding durability after opening of the packaging. This information can become even better with extended guidance, as in the example with pesto. For products labelled with "best before" where growth of pathogenic microorganisms or mould toxins does not happen, it is desirable that producers give consumers information that the product - if it has been stored according to instructions - can be eaten as long as it looks good, smells good and tastes good. The text should not be placed as part of the date labelling text, so as not to confuse consumers - the date labelling text must be easy to find and read.

\author{
Consumer guidance \\ can be given by giving \\ additional information, \\ as in this example with \\ pesto: \\ "Opened packaging \\ is durable for one week \\ in the refrigerator if \\ the content is covered \\ in oil". This type of \\ guidance can help \\ the consumer to \\ avoid food waste.
}




\section{RECOMMENDATIONS AND FURTHER WORK}

The project has given the following recommendations:

- Durability labelling should be chosen carefully. "Use by" applies to food safety and should only be used on highly perishable food items where the storage time can lead to an immediate health risk despite storing according to instructions.

- Better guidance to the food processing industry, retail and consumers. For the food processing industry and the retail stores it is recommended to develop guidelines for "best practice". Consumer information about date labelling and durability of food products needs to reach out in a much higher degree. Likewise it is important to inform the consumers regarding storage and handling of foods, which is critical for the durability.

- To work on the possibility of a harmonisation for lower storage temperatures for perishable foods in Sweden, Denmark and Finland.

- The Nordic project group recommends that eggs should be regulated like any other food items where the producer is responsible for establishing the durability and provide information regarding storage requirements. As long as the current legislation applies, there will be more need for consumer guidance regarding the durability of eggs. 

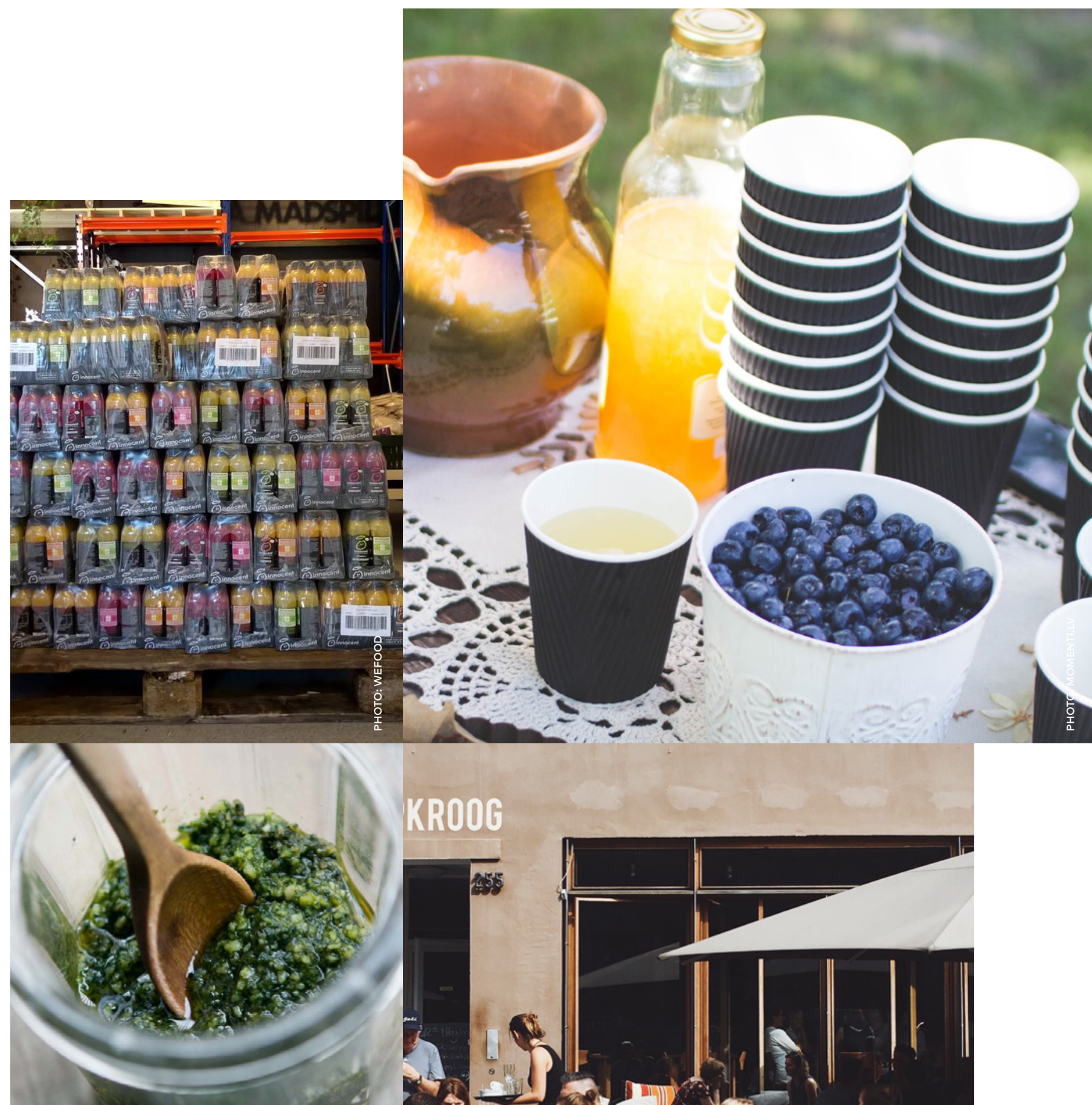

KROOG

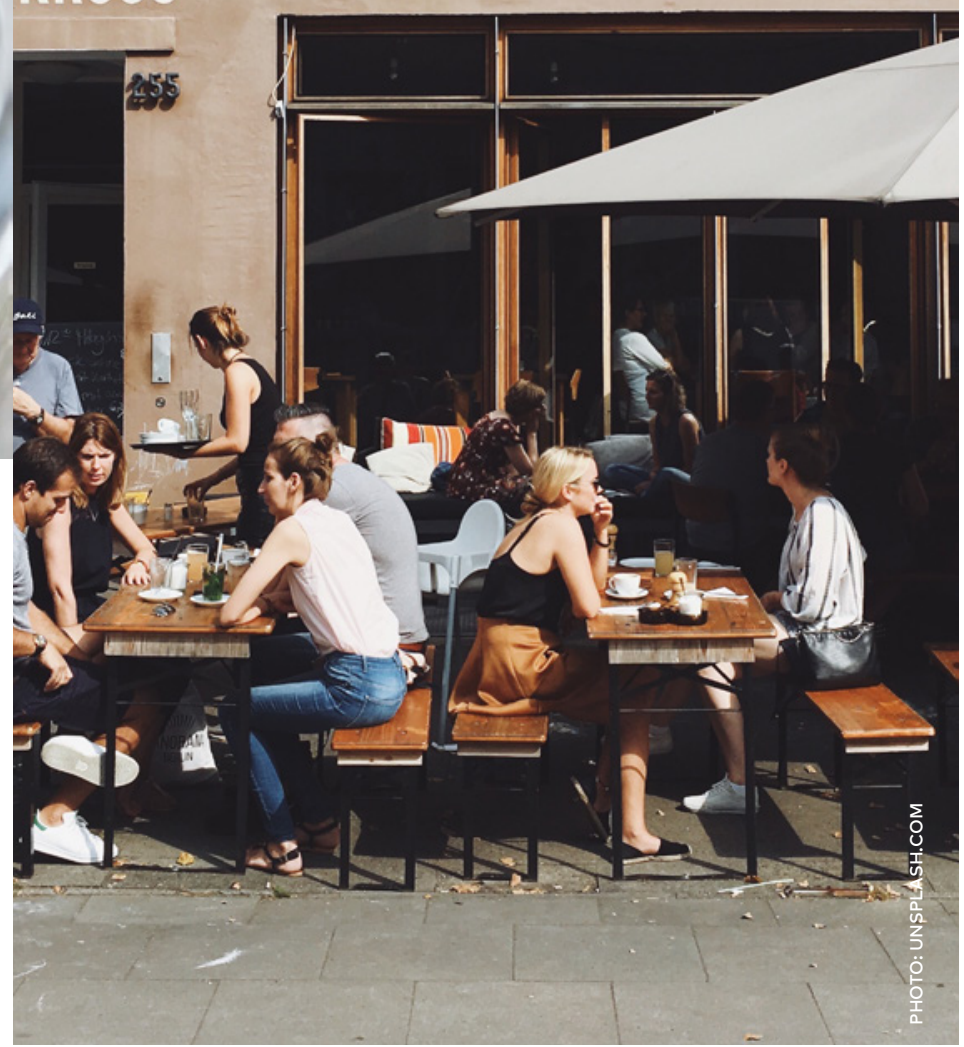




\section{Nordic Council of Ministers}

Nordens Hus

Ved Stranden 18

DK-1061 Copenhagen

www.norden.org 